\title{
Nitrogen removal in coastal sediments of the German Wadden Sea
}

\author{
Astrid Deek · Kay Emeis $\cdot$ Justus van Beusekom
}

Received: 27 July 2010/ Accepted: 26 May 2011/Published online: 9 June 2011

(C) Springer Science+Business Media B.V. 2011

\begin{abstract}
Although sediments of the German Wadden Sea are suspected to eliminate a considerable share of nitrate delivered to the SE North Sea, their denitrification rates have not been systematically assessed. We determined $\mathrm{N}_{2}$ production rates over seasonal cycles (February 2009-April 2010) at two locations with two sediments types each, the first site (Meldorf Bight) receiving nitrate during all seasons from the Elbe river plume, and a second site on the island of Sylt, where nitrate is depleted during summer months. In sediments from the Sylt site, $\mathrm{N}_{2}$ production ranged from 15 to $32 \mu \mathrm{mol} \mathrm{N} \mathrm{m}^{-2} \mathrm{~h}^{-1}$ in the fine sand station and from 7 to $13 \mu \mathrm{mol} \mathrm{N} \mathrm{m}^{-2} \mathrm{~h}^{-1}$ in the coarse sand station; $\mathrm{N}_{2}$ production was not detected when nitrate was depleted in May and July of 2009. $\mathrm{N}_{2}$ production in the Meldorf
\end{abstract}

A. Deek - K. Emeis

Helmholtz-Zentrum Geesthacht, Institute for Coastal

Research, Max-Planck-Str. 1, 21502 Geesthacht, Germany

A. Deek · K. Emeis

IfBM, University of Hamburg, Bundesstr. 55,

20146 Hamburg, Germany

J. van Beusekom

AWI, Alfred-Wegener-Institute for Polar and Marine

Science, Wadden Sea Station Sylt, Hafenstrasse 43,

25992 List/Sylt, Germany

Present Address:

A. Deek $(\square)$

Institute for Environmental Geoscience, University of Basel, Bernoullistrasse 30, 4056 Basel, Switzerland

e-mail: astrid.deek@unibas.ch
Bight sediments were consistently detected at higher rates $\left(58-130 \mu \mathrm{mol} \mathrm{N} \mathrm{N}_{2} \mathrm{~m}^{-2} \mathrm{~h}^{-1}\right.$ in the very fine sand station and between 14 and $30 \mu \mathrm{mol} \mathrm{N} \mathrm{m}^{-2} \mathrm{~h}^{-1}$ in the medium sand station). Analysis of ancillary parameters suggests that major factors controlling $\mathrm{N}_{2}$ production in coastal sediments of the German Wadden Sea are the nitrate concentrations in the overlying water, the ambient temperature, and the organic matter content of the sediment. Extrapolating our spot measurements to the zone of nitrate availability and sediment types, we estimate an annual nitrogen removal rate around $16 \mathrm{kt}$ $\mathrm{N}$ year ${ }^{-1}$ for the entire northern sector of the German Wadden Sea area. This corresponds to $14 \%$ of the annual Elbe river nitrogen load.

Keywords Denitrification · Nitrogen - Sediments · Wadden Sea · German Bight · Incubation

\section{Introduction}

Reactive nitrogen (rN) inputs to the North Sea by rivers have increased 3-fold since the 1960's (van Beusekom and de Jonge 2002) and are considered to be a prime reason for environmental deterioration in offshore regions of the North Sea (Owens et al. 1990) and in the Wadden Sea area (van Beusekom et al. 2001; van Beusekom and de Jonge 2002). Mass balance estimates (Pätsch et al. 2010) suggest that increased atmospheric and riverine $\mathrm{rN}$ inputs are mitigated by effective sinks, such as sedimentary 
denitrification in subtidal and intertidal sediments of the shallow North Sea. These sediments receive constantly high organic matter loadings (van Beusekom and de Jonge 2002) and are permeable, so that nitrate is readily advected to suboxic depth levels. These suboxic sediment layers thus are active sites of denitrification, during which $\mathrm{NO}_{3}{ }^{-}$and $\mathrm{NO}_{2}{ }^{-}$are reduced via $\mathrm{NO}$ and $\mathrm{N}_{2} \mathrm{O}$ to $\mathrm{N}_{2}$. The latter escapes from the sediment to the overlying water or atmosphere by diffusion (Nixon et al. 1996) and is lost from the system. Together with the process of anaerobic ammonia oxidation, which is less well studied, denitrification in sediments is the most important sink for nitrate on a global scale and a first order regulation mechanism for the nitrogen cycle of shelf seas (Middelburg et al. 1996; Middelburg and Soetaert 2004). Controlling factors for denitrification rates in coastal sediments are amount and quality of sedimentary organic matter, concentrations of nitrate in water overlying the sediment, permeability of the sediment, and secondary factors, such as bioturbation/ bio-irrigation, macrophytes and availability of manganese and iron (Cornwell et al. 1999). Although of considerable value as an ecosystem service that eliminates excess nitrate in and counteracts eutrophication of coastal zones, knowledge of denitrification rates in the sediments of the North Sea is limited. Experimental data were obtained in the 1990's with methods (the acetylene blocking technique) that may underestimate actual denitrification rates (Sørensen 1978; Lohse et al. 1993; Lohse et al. 1996). Budget estimates generally give higher $\mathrm{N}$ loss rates than available measurements (Brion et al. 2004). van Beusekom and van de Jonge (1998) estimated annual denitrification rates of about $900 \mathrm{mmol} \mathrm{N} \mathrm{m}^{-2}$ year $^{-1}$ for the Ems estuary based on nutrient-salinity relations and input data. Hydes et al. (1999) regarded the Southern North Sea as a giant estuary and estimated an average denitrification in the Southern North Sea of about $256 \mathrm{mmol} \mathrm{N} \mathrm{m}^{-2}$ year $^{-1}$. Brion et al. (2004) used similar rates for their North Sea budget. Only limited information using modern techniques like the $\mathrm{N}_{2} / \mathrm{Ar}$ method is available to support the high denitrification rates as suggested by budget calculations. Two studies carried out within the Wadden Sea focussed on experimental techniques and reported potential denitrification rates (after addition of ${ }^{15} \mathrm{~N}$ labelled nitrate) (Cook et al. 2006; Gao et al. 2010). These rates were among the highest ever measured in the Wadden Sea, comparable to the above rates as derived from budgets, but lack spatial and temporal resolution.

Our main objective here was to improve the seasonal and spatial resolution of sedimentary $\mathrm{N}_{2}$ production measurements as an indication of nitrogen removal in intertidal sediments of the Wadden Sea. Our approach was to determine nitrogen removal rates along gradients of nitrate availability, sediment type and organic matter content, and ambient temperature. By extrapolation of determined $\mathrm{N}_{2}$ production rates, we estimated the overall nitrogen loss in the entire Wadden Sea.

\section{Materials and methods}

We quantified $\mathrm{N}_{2}$ production rates using a direct flux approach by incubating undisturbed sediment cores in a flow-through incubation set-up (modified after Lavrentyev et al. 2000; McCarthy and Gardner 2003) and measuring $\mathrm{N}_{2}$ fluxes by the $\mathrm{N}_{2} / \mathrm{Ar}$ technique (Kana et al. 1994; An et al. 2001). The incubation design allowed us to quantify net $\mathrm{N}_{2}$ fluxes in sediment cores incubated with ambient site water, and to calculate denitrification rates according to the isotope pairing technique in sediment cores incubated with site water enriched by ${ }^{15} \mathrm{NO}_{3}{ }^{-}$. We conducted sampling campaigns in different seasons and at sites with varying sediment types to bracket the most significant gradients in environmental parameters listed in the introduction (Cornwell et al. 1999).

\section{Study sites}

In the northern Wadden Sea of the German Bight, nitrate gradients are steep and mirror the decreasing influence of the Elbe River plume. We selected two study sites along the nitrate gradient: Near the plume, at study site Büsum/Meldorf Bight (Fig. 1), nitrate is never depleted in waters in contact with sediments. The site near the island of Sylt has no or negligible nitrate and low ammonium concentrations between July and September (van Beusekom et al. 2009). At each site, two different sediment types in terms of grain size distribution and organic matter content were sampled (Table 1). 
Fig. 1 Study sites in the North Frisian Wadden Sea

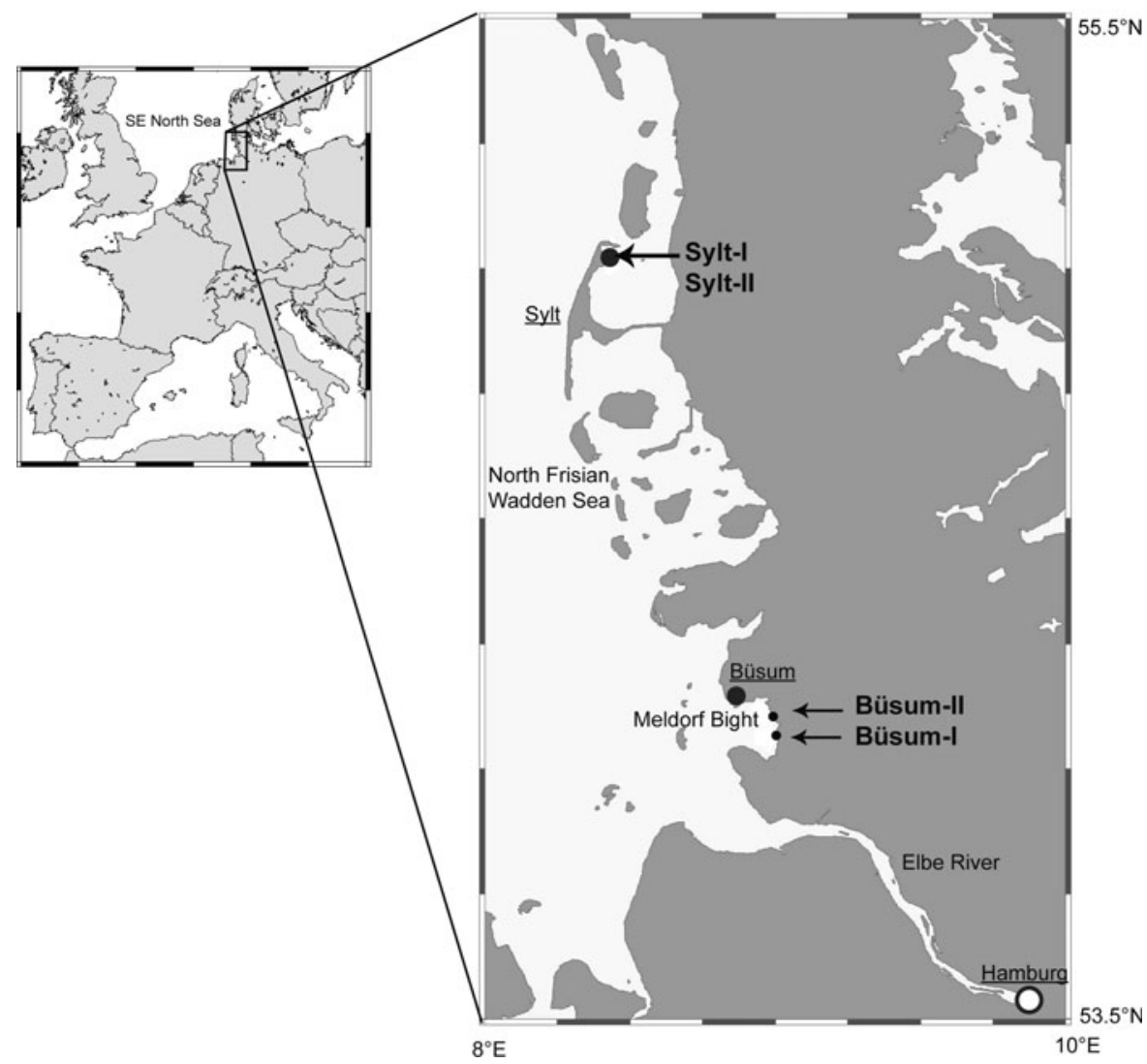

Table 1 Sediment characteristics for the study sites Sylt-I, Sylt-II, Büsum-I and Büsum-II (Porosity, carbon content (\%C), nitrogen content $(\% \mathrm{~N})$, organic carbon content $\left(\% \mathrm{C}_{\text {org }}\right)$ and $\mathrm{C} / \mathrm{N}$ given as average value with standard deviation for 10 sediment slices from one core of $10 \mathrm{~cm}$ length (depth resolution: $1 \mathrm{~cm}$ ); amino acids (AA) were analyzed in surface sediment layers: $0-1 \mathrm{~cm}$; median grain size given for $10 \mathrm{~cm}$; sediments were classified according the Udden-Wenthworth size scale (Wentworth 1922; Pettijohn and Potter 1972)

\begin{tabular}{llllllrrrr}
\hline Month & Station & \multicolumn{1}{l}{$\begin{array}{l}\text { Porosity } \\
(\mathrm{v} / \mathrm{v})\end{array}$} & $\mathrm{C}(\%)$ & $\mathrm{N}(\%)$ & $\mathrm{C}_{\mathrm{org}}(\%)$ & $\mathrm{C} / \mathrm{N}$ & $\begin{array}{l}\mathrm{AA} \\
\left(\mathrm{mg} \mathrm{g}^{-1}\right)\end{array}$ & $\begin{array}{l}\text { Median } \\
\text { grain } \\
\text { size }(\mu \mathrm{m})\end{array}$ & $\begin{array}{l}\text { Sediment } \\
\text { classification }\end{array}$ \\
\hline June'09 & Büsum-I & $0.67 \pm 0.13$ & $29 \pm 0.4$ & $022 \pm 005$ & $19 \pm 04$ & $95 \pm 03$ & 7 & 63 & Very fine sand \\
& Büsum-11 & $0.42 \pm 0,02$ & $0.5 \pm 0.1$ & $0.1 \pm 0.04$ & $0.1 \pm 0.1$ & $5.9 \pm 0.4$ & 0.6 & 250 & Medium sand \\
July'09 & Sylt-I & $0.73 \pm 0.06$ & $2.1 \pm 0.8$ & $0.21 \pm 0.12$ & $1.6 \pm 0.6$ & $7.5 \pm 0.7$ & 14.9 & 125 & Fine sand \\
& Sylt-II & $0.42 \pm 0.09$ & $0.7 \pm 0.4$ & $0.05 \pm 0.06$ & $0.6 \pm 0.4$ & $13.7 \pm 0.4$ & 0.8 & 500 & Coarse sand \\
\hline
\end{tabular}

\section{Sampling}

At least six sediment cores were taken during each sampling campaign at each of the sampling stations of the two sites. These stations were sampled at the beginning of high tide, when the sediment was covered by a water column of at least $10 \mathrm{~cm}$ and a maximum of
$30 \mathrm{~cm}$. Samples (around $20 \mathrm{~cm}$ length) were taken manually with polyvinylchloride (PVC) tubes $(60 \mathrm{~cm}$ length and inner diameter of $10 \mathrm{~cm}$ ) and stoppered. After sampling, the upper rubber stopper was removed and water level overlying the sediment was adjusted to $10 \mathrm{~cm}$. Sediment cores were cooled and transported $(<6 \mathrm{~h})$ to the temperature-controlled 
Table 2 Site parameters for the sampling campaigns in Sylt and Büsum

\begin{tabular}{|c|c|c|c|c|c|c|c|c|c|c|c|}
\hline \multirow[t]{2}{*}{ Station } & \multirow[t]{2}{*}{ Month } & \multicolumn{2}{|c|}{ Water column } & \multirow[t]{2}{*}{$\mathrm{pH}$} & \multirow{2}{*}{$\begin{array}{l}\mathrm{PO}_{4}^{-} \\
(\mu \mathrm{mol} / \mathrm{l})\end{array}$} & \multirow{2}{*}{$\begin{array}{l}\mathrm{Si} \\
(\mu \mathrm{mol} / 1)\end{array}$} & \multirow{2}{*}{$\begin{array}{l}\mathrm{NH}_{4}^{+} \\
(\mu \mathrm{mol} / 1)\end{array}$} & \multirow{2}{*}{$\begin{array}{l}\mathrm{NO}_{3}{ }^{-} \\
(\mu \mathrm{mol} / 1)\end{array}$} & \multirow{2}{*}{$\begin{array}{l}\mathrm{NO}_{2}^{-} \\
(\mu \mathrm{mol} / 1)\end{array}$} & \multirow{2}{*}{\multicolumn{2}{|c|}{$\begin{array}{l}\text { Sediment } \\
\text { Oxygen } \\
\text { penetration } \\
\text { depth }(\mathrm{mm})\end{array}$}} \\
\hline & & $\mathrm{T}\left({ }^{\circ} \mathrm{C}\right)$ & Sal & & & & & & & & \\
\hline \multirow[t]{5}{*}{ Büsum } & & & & & & & & & & Büsum-I & Büsum-1l \\
\hline & February'09 & 4 & 18 & 8.6 & 6.0 & 18.0 & 23.7 & 67.4 & 1.5 & 1.5 & 2.6 \\
\hline & June'09 & 23 & 30 & 8.0 & 2.6 & 18.9 & 14.2 & 6.8 & 1.3 & 0.8 & 2.2 \\
\hline & November'09 & 8 & 20 & 8.0 & 5.2 & 87.3 & 31.0 & 67.2 & 4.2 & 2.6 & 3.0 \\
\hline & April'10 & 9 & 30 & 8.5 & n.d. & 20.6 & 1.4 & 85.4 & 4.6 & 1.4 & 1.6 \\
\hline \multirow[t]{6}{*}{ Sylt } & & & & & & & & & & Sylt-I & Sylt-11 \\
\hline & February’09 & 1 & 30 & 8.2 & 2.3 & 10.4 & 4.7 & 31.9 & n.d. & 2.2 & 3.1 \\
\hline & May'09 & 15 & 30 & - & 1.2 & 7.8 & n.d. & n.d. & n.d. & 1.2 & 1.6 \\
\hline & July'09 & 24 & 32 & 8.3 & 0.6 & 3.8 & 1.3 & n.d. & n.d. & 1.2 & 1.7 \\
\hline & November'09 & 8 & 30 & 8.8 & 1.3 & 10.8 & 10.3 & 12.1 & 0.8 & 1.8 & - \\
\hline & April'10 & 8 & 30 & 8.5 & 0.2 & 1.7 & 4.8 & 13.0 & 1.3 & 1.2 & 2.0 \\
\hline
\end{tabular}

(n.d. not detected; - data not available)

laboratory. At least 1001 of site water were collected in 251 carboys to ensure sufficient site water with appropriate salinity and nutrient concentrations for the flow-through incubation.

At the sample site, $50 \mathrm{ml}$ of site water were filtered through a $0.2 \mu \mathrm{m}$ syringe filter (X50 Analypore, PVDF) and stored frozen until analysis of ambient nutrient concentrations as described in "Nutrient concentrations" section. $\mathrm{O}_{2}$ saturation and temperature of site water were measured with an Ecoscan DO 6 (Eutech Instruments), salinity with a handheld refractometer (Atego), and $\mathrm{pH}$ with an Ecoscan Ion 6 (Eutech Instruments) (Table 2).

\section{Sediment core incubation}

After transferring the cores to a temperature controlled room or into a circulating water bath adjusted to the in situ temperature, the supernatant water was aerated with aquarium pumps for $6-12 \mathrm{~h}$ to reach oxygen saturation in the overlying water column before starting the incubation. The incubation set-up is a modified and larger version of the incubation setups described in Gardner et al. (1991), Lavrentyev et al. (2000) and McCarthy and Gardner (2003). The sediment cores were wrapped with aluminium foil to prevent variable light conditions, and were placed in a flow-through incubation system, consisting of the cores, a 251 carboy of site water, a peristaltic pump and an outflow collection vessel. The site water reservoir was aerated constantly, because the ambient water at the study sites was always oxygen saturated during all sampling campaigns. The sediment cores were locked with a gas tight plunger with two O-rings and Tygon inflow and outflow tubes. The plunger was positioned to $5 \mathrm{~cm}$ above the sediment-water interface, which is equal to a water volume of $785 \mathrm{ml}$ over the sediment, continuously replaced by site water at a rate of $1-2 \mathrm{ml} \mathrm{min}^{-1}$. Samples of inflow water and outflow water were taken every $12 \mathrm{~h}$ of incubation for $\mathrm{N}_{2}$ and $\mathrm{O}_{2}$ measurements and every $24 \mathrm{~h}$ of incubation for nutrient analysis. Two control cores without sediment were run in the same way to exclude water column denitrification. Whereas the incubations of Sylt-I and Büsum-I cores were run for 2 days, the incubations of Sylt-II and Büsum-II cores were run for 4 days. The different incubation times were necessary to account for the different sediment types: In preliminary incubation tests, sandy sediments had reached steady-state fluxes of nutrients, $\mathrm{O}_{2}$ and $\mathrm{N}_{2}$ only after longer incubation times, explained by deeper oxygen penetration (Table 2) and deeper denitrification zones in sandy sediments (Cook et al. 2006; Gihring et al. 2010). 
Core incubations with site water (unamended cores)

Three of the 6 subcores were incubated with untreated site water. From the unamended cores, actual net $\mathrm{N}_{2}$ fluxes $(\mathrm{m} 28)$ and $\mathrm{O}_{2}$ fluxes were measured under actual conditions with ambient nitrate concentrations at the sampling site (Table 2). Rate determinations were conducted as described in "Determination of actual net $\mathrm{N}_{2}$ and $\mathrm{O}_{2}$ fluxes" section.

\section{Core incubation with site water enriched with ${ }^{15} \mathrm{NO}_{3}{ }^{-}$(amended cores)}

Three of the 6 subcores were incubated with site water enriched with $\mathrm{Na}^{15} \mathrm{NO}_{3}{ }^{-}$(98 atom $\%{ }^{15} \mathrm{~N}$, Isotec). Whereas natural nitrate concentration of site water varied with sampling campaign as documented in Table 2, labeling of ${ }^{15} \mathrm{NO}_{3}{ }^{-}$was always to a $40-50 \mu \mathrm{mol} / \mathrm{l}^{15} \mathrm{NO}_{3}{ }^{-}$concentration, resulting in varying relative nitrate enrichment over natural conditions.

$\mathrm{N}_{2}$ fluxes $(\mathrm{m} 29+\mathrm{m} 30)$ from these amended cores were used (a) to estimate $\mathrm{N}_{2}$ fluxes under conditions when actual $\mathrm{NO}_{3}{ }^{-}$limitation is alleviated through artificial ${ }^{15} \mathrm{NO}_{3}{ }^{-}$addition, and (b) to calculate denitrification rates according to the isotope pairing technique (Nielsen 1992), as described in "Calculation of $\mathrm{N}_{2}$ production rates from amended cores according to IPT" section.

\section{Laboratory analyses and rate determinations}

Triplicate samples from the inflow water and outflow water of unamended and amended cores were taken every $12 \mathrm{~h}$ with cylindrical glass vials during incubations and were analyzed immediately after collection for $\mathrm{N}_{2}$ and $\mathrm{O}_{2}$. The concentrations of $\mathrm{N}_{2}$ and $\mathrm{O}_{2}$ were calculated from $\mathrm{N}_{2} / \mathrm{Ar}$ and $\mathrm{O}_{2} / \mathrm{Ar}$ ratios measured with a membrane inlet mass spectrometry (MIMS) system consisting of a Quadrupole mass spectrometer (QMS) (GAM 200, InProcess Instruments) with a modified membrane inlet from Bay Instruments. The MIMS was standardized with air saturated temperature-salinity-standards according to Kana et al. (1994) to correct measured $\mathrm{N}_{2} / \mathrm{Ar}$ and $\mathrm{O}_{2} / \mathrm{Ar}$ ratios to actual ratios. Concentrations were calculated by multiplying the actual Ar concentration from solubility tables (Weiss 1970) with the corrected ratio. The QMS ion source produces $\mathrm{O}^{+}$ions by ionizing sample gas; $\mathrm{O}^{+}$ ions may react with $\mathrm{N}_{2}$ forming $\mathrm{NO}_{\mathrm{x}}$ (Eyre et al.
2002). This so called $\mathrm{NO}_{x}$-effect results in higher signals on mass $28(\mathrm{~m} 28)$ at low oxygen concentrations and low $\mathrm{m} 28$ signals at high oxygen concentrations, which may lead to a misinterpretation of actual denitrification. The $\mathrm{NO}_{x}$-effect was tested for the MIMS system used here and the extent of this effect was found to be below the standard deviation of the method (0.1\%) (J. Pohlmann, pers. comm. 2010).

$\mathrm{N}_{2}$ and $\mathrm{O}_{2}$ fluxes ( $\mathrm{fl}$; in $\mu \mathrm{mol} \mathrm{m} \mathrm{m}^{-2} \mathrm{~h}^{-1}$ ) were calculated by subtracting inflow concentration $\left(\mathrm{C}_{\mathrm{i}}\right)$ from outflow concentration $\left(\mathrm{C}_{\mathrm{o}}\right)$ multiplied with the flow rate $\left(\mathrm{f}: \mathrm{l} \mathrm{h}^{-1}\right)$ and sediment surface area $\left(\mathrm{a}: \mathrm{m}^{2}\right)$ ratio:

$\mathrm{fl}=\left(\mathrm{C}_{\mathrm{o}}-\mathrm{C}_{\mathrm{i}}\right) \times \mathrm{f} / \mathrm{a}$.

Determination of actual net $\mathrm{N}_{2}$ and $\mathrm{O}_{2}$ fluxes

Net $\mathrm{N}_{2}$ and $\mathrm{O}_{2}$ fluxes were determined from the water samples of the unamended cores by MIMS measurements of $\mathrm{N}_{2}$ on mass 28 and $\mathrm{O}_{2}$ on mass 32, and inserting respective inflow and outflow concentration data into Eq. 1. In the following, net $\mathrm{N}_{2}$ and $\mathrm{O}_{2}$ fluxes are also referred to as actual fluxes.

\section{Calculation of $\mathrm{N}_{2}$ production rates from amended} cores according to IPT

From the water samples of the amended cores $\mathrm{N}_{2}$ fluxes were determined by MIMS measurements on mass 29 and mass 30. Production rates of ${ }^{29} \mathrm{~N}_{2}$ and ${ }^{30} \mathrm{~N}_{2}$ were calculated according to Eq. 1 .

The obtained ${ }^{29} \mathrm{~N}_{2}$ and ${ }^{30} \mathrm{~N}_{2}$ production rates allow estimates of $\mathrm{N}_{2}$ production based on (natural) ${ }^{14} \mathrm{NO}_{3}{ }^{-}$ $\left(\mathrm{D}_{14}\right)$ and (added) ${ }^{15} \mathrm{NO}_{3}{ }^{-}\left(\mathrm{D}_{15}\right)$ to be made with equations used in the isotope pairing technique (IPT) (Nielsen 1992). $D_{15}$ is calculated as follows:

$\mathrm{D}_{15}=2 \times \mathrm{N}_{2}(\mathrm{~m} 30)+\mathrm{N}_{2}(\mathrm{~m} 29)$,

where $\mathrm{N}_{2}(\mathrm{~m} 30)$ is the net $\mathrm{N}_{2}$ production rate on $\mathrm{m} 30$ and $\mathrm{N}_{2}(\mathrm{~m} 29)$ is the net $\mathrm{N}_{2}$ production rate on $\mathrm{m} 29$.

For the calculation of the denitrification rate based on ambient ${ }^{14} \mathrm{NO}_{3}{ }^{-}\left(\mathrm{D}_{14}\right)$ Eq. 3 applies:

$\mathrm{D}_{14}=\left[\mathrm{N}_{2}(\mathrm{~m} 29) /\left(2 \times \mathrm{N}_{2}(\mathrm{~m} 30)\right)\right] \times \mathrm{D}_{15}$.

The total denitrification rate is:

$\mathrm{D}_{\text {tot }}=\mathrm{D}_{14}+\mathrm{D}_{15}$.

We also estimated the proportion of coupled nitrification-denitrification $\left(\mathrm{D}_{\mathrm{n}}\right)$ as opposed to 
denitrification of nitrate from the overlying water $\left(D_{w}\right)$ (Nielsen 1992; Steingruber et al. 2001):

$\mathrm{D}_{\mathrm{w}}[\%]=\left(\mathrm{D}_{15} / \varepsilon\right) \times 100 / \mathrm{D}_{\text {tot }}$,

where $\varepsilon$ represents the relative ${ }^{15} \mathrm{NO}_{3}{ }^{-}$enrichment during the core incubation.

From Eqs. 4 and 5, coupled nitrification-denitrification can be estimated:

$\mathrm{D}_{\mathrm{n}}[\%]=100-\mathrm{D}_{\mathrm{W}}$.

The parallel measurement of net $\mathrm{N}_{2}$ production rates measured in unamended cores and the calculation of $\mathrm{N}_{2}$ production rates $\left(\mathrm{D}_{14}\right)$ from amended cores of the same site furthermore allowed estimation of $\mathrm{N}_{2}$ production and consumption rates based on calculations proposed by An et al. (2001).

\section{Nutrient concentrations}

During each sampling campaign, a sample of $50 \mathrm{~mL}$ site water was collected to determine ambient nutrient concentrations of inflow water at the beginning of flow-through incubation. Every $24 \mathrm{~h}$ during incubation, a $50 \mathrm{ml}$ sample from each inflow and outflow of unamended and amended cores was collected for nutrient analyses. Water samples were filtered using a $0.2 \mu \mathrm{m}$ syringe filter (X50 Analypore, PVDF) and were stored frozen in Falcon tubes until analysis.

Nutrient concentrations were determined photometrically on an automated continuous flow system (Bran \& Luebbe Auto Analyzer 3) using standard methods of seawater analysis: nitrate and nitrite concentrations were determined according to Armstrong et al. 1967), ammonium concentrations according to Grasshoff et al. (1983), phosphate concentrations according to Murphy and Riley (1962), and silicate concentrations according to Brewer and Riley (1966). The relative error of triplicate sample measurements was below $1.5 \%$ for nitrate, nitrite and phosphate concentrations, and below $4.8 \%$ for ammonium concentrations.

Nutrient fluxes were calculated according to Eq. 1. In the following, nutrient fluxes in the unamended cores are also referred to as actual fluxes.

\section{Sediment characteristics}

Before incubation, oxygen penetration depths were determined for one sediment core from each sampling station. Triplicate profiles were performed at three different positions in each sediment core (a total of nine profiles); the precision of this determination was better than $0.5 \mathrm{~mm}$. Two different types of oxygen profiling setups were used during this study: A Clark-type $\mathrm{O}_{2}$ micro electrode (OX 50 and $\mathrm{OX}$ 100 ) in connection with a picoamperemeter (Unisense $\mathrm{A} / \mathrm{S}$ ), and an oxygen micro-optode (Oxy $50 \mathrm{M}$, Pyro Science) in connection with a Microx TX3-USB (Pyro Science, Presens).

Sediment characteristics were determined on sediment cores from sampling campaigns in June 2009 (Büsum-I and Büsum-II) and in July 2009 (Sylt-I and Sylt-II). For each sampling site, a sediment core with a length of $10 \mathrm{~cm}$ was sliced into $1 \mathrm{~cm}$ slices of known volume and frozen for transport.

Water content and porosity were calculated from the weight before and after freeze drying and assuming a grain density of $2.65 \mathrm{~g} \mathrm{~cm}^{-3}$. Grain size distribution was then determined on dry residues by sieving through mesh sizes of 1000, 500, 250, 125 and $63 \mu \mathrm{m}$. The weight percentage of total nitrogen (TN) and organic carbon $\left(\mathrm{C}_{\text {org }}\right)$ were determined with an Elemental Analyzer (Thermo Flash EA) calibrated against acetanilide on dried and homogenised subsamples of unsieved sediments (in $1 \mathrm{~cm}$ slices). The standard deviation of duplicate analyses was below $0.05 \%$ for carbon and below $0.005 \%$ for nitrogen.

Total hydrolysable amino acids (AA) were analysed in surface sediments $(0-1 \mathrm{~cm})$ with a Biochrom 30 AA Analyser after hydrolysis of $30-50 \mathrm{mg}$ of sediment with $6 \mathrm{~N} \mathrm{HCl}$ for $22 \mathrm{~h}$ at $110^{\circ} \mathrm{C}$. $\mathrm{HCl}$ was then removed by evaporation and the residue was taken up by acidic buffer and injected into the analyser. The relative error for total AA was $4 \%$.

\section{Results}

Sediment characteristics at the different sites

Properties of sediments at each of the sample locations are listed in Table 1. These parameters were only determined once on one core from each sediment facies (see sections "Study sites", "Sediment characteristics"). The highest organic carbon content together with highest total hydrolysable AA concentrations were measured in cores of Sylt-I and 
Büsum-I, which suggests that substrate quality in terms of labile particulate matter available for bacterial respiration was highest at these stations.

Seasonal variation of the site parameters

Stations in the Meldorf Bight (Büsum-I and BüsumII) and on Sylt (Sylt-I and Sylt-II) experienced a pronounced seasonal variability of site parameters (Table 2). High water temperatures as measured during summer months (May-July) were accompanied by comparatively low nutrient concentrations in the water column. At Sylt sites, $\mathrm{NO}_{3}{ }^{-}, \mathrm{NO}_{2}{ }^{-}$and $\mathrm{NH}_{4}{ }^{+}$concentrations were even below detection limit in May 2009. The oxygen penetration depth of the sediments varied similarly with season, lowest oxygen penetration depths were measured at high water temperatures during summer months.

\section{Nutrient fluxes}

Nutrient fluxes across the sediment-water interface of incubated cores were determined every $24 \mathrm{~h}$ of incubation. For simplification, nutrient fluxes are only given for the steady state. Table 3 depicts $\mathrm{NO}_{3}{ }^{-}$ and $\mathrm{NH}_{4}{ }^{+}$fluxes (mean value of three cores) for the unamended cores on day 2 of incubation for Büsum-I and Sylt-I and on day 4 of incubation for Büsum-II and Sylt-II (all at steady state). In the following, $\mathrm{NO}_{3}{ }^{-}$and $\mathrm{NH}_{4}{ }^{+}$fluxes from the unamended cores are referred to as actual fluxes. In Table $4, \mathrm{NO}_{3}{ }^{-}$and $\mathrm{NH}_{4}{ }^{+}$fluxes from ${ }^{15} \mathrm{NO}_{3}{ }^{-}$amended cores are listed for the same situation (with negative values denoting flux into the sediment).

Highest ammonium fluxes were measured in the Büsum-I and Sylt-I cores which both have a relatively high organic carbon content (Table 1).

Highest actual $\mathrm{NO}_{3}{ }^{-}$fluxes were measured in the Büsum-I and Büsum-II cores in June 2009 and April 2010 (Table 3). In the Sylt cores, no significant actual nitrate fluxes were measured during May and July 2009 (Table 3) when water temperature was highest, but no ambient nitrate was left in the water column (Table 1), whereas significant $\mathrm{NO}_{3}{ }^{-}$fluxes in the ${ }^{15} \mathrm{NO}_{3}{ }^{-}$amended incubations were measured during summer months at the Sylt sites (Table 4).
Table 3 Nitrate and ammonium fluxes for the unamended cores

\begin{tabular}{|c|c|c|c|}
\hline Station & Month & $\begin{array}{l}\mathrm{NO}_{3}^{-} \text {flux } \\
\left(\mu \mathrm{mol} \mathrm{m} \mathrm{m}^{-2} \mathrm{~h}^{-1}\right)\end{array}$ & $\mathrm{NH}_{4}^{+}$flux \\
\hline \multirow[t]{4}{*}{ Büsum-I } & February'09 & $-255 \pm 28$ & $-150 \pm 12$ \\
\hline & June'09 & $-412 \pm 10$ & $203 \pm 30$ \\
\hline & November'09 & $-71 \pm 2$ & $135 \pm 40$ \\
\hline & April'10 & $-298 \pm 70$ & $32 \pm 5$ \\
\hline \multirow[t]{4}{*}{ Büsum-II } & February'09 & $-62 \pm 9$ & $-78 \pm 7$ \\
\hline & June'09 & $-197 \pm 3$ & $-101 \pm 15$ \\
\hline & November'09 & $-54 \pm 10$ & $-178 \pm 30$ \\
\hline & April'10 & $-246 \pm 67$ & $26 \pm 8$ \\
\hline \multirow[t]{5}{*}{ Sylt-I } & February'09 & $-24 \pm 9$ & $88 \pm 23$ \\
\hline & Мay'09 & n.d. & $335 \pm 104$ \\
\hline & July'09 & n. d. & $515 \pm 36$ \\
\hline & November'09 & $-48 \pm 5$ & $487 \pm 78$ \\
\hline & April'10 & $-19 \pm 11$ & $35 \pm 15$ \\
\hline \multirow[t]{5}{*}{ Sylt-II } & February'09 & $-23 \pm 4$ & $-10 \pm 24$ \\
\hline & May’09 & n.d. & $83 \pm 3$ \\
\hline & July'09 & n.d. & $0 \pm 69$ \\
\hline & November'09 & $-184 \pm 26$ & $4 \pm 8$ \\
\hline & April'10 & $-16 \pm 4$ & $52 \pm 30$ \\
\hline
\end{tabular}

$\overline{\text { Data are mean values of three cores }(n=3) \text { with standard }}$ deviation

n.d. not detected

$\mathrm{N}_{2}$ and $\mathrm{O}_{2}$ fluxes

$\mathrm{N}_{2}$ and $\mathrm{O}_{2}$ fluxes (mean value of three cores) are given in Tables 5 and 6; again fluxes refer to day 2 of incubation for Büsum-I and Sylt-I and to day 4 of incubation for Büsum-II and Sylt-II (all at steady state).

Sedimentary oxygen demand (SOD) was highest in November 2009 at all sampling stations and lowest in February 2009 (Table 5).

Tables 5 and 6 also compare four different $\mathrm{N}_{2}$ fluxes obtained simultaneously by the incubation of six cores: (1) Actual net $\mathrm{N}_{2}$ fluxes on mass 28 from three unamended cores (Table 5), incubated as described in "Core incubations with site water (unamended cores)". (2) and (3) $\mathrm{N}_{2}$ fluxes on mass 29 and mass 30 from three amended cores (Table 6), in which ambient ${ }^{14} \mathrm{NO}_{3}{ }^{-}$is partially combined with added ${ }^{15} \mathrm{NO}_{3}{ }^{-}$as described in "Core incubation with site water enriched with ${ }^{15} \mathrm{NO}_{3}{ }^{-}$(amended cores)" section. (4) the $\mathrm{N}_{2}$ production rate $\left(\mathrm{D}_{14}\right)$ calculated 
Table 4 Nitrate and ammonium fluxes for the ${ }^{15} \mathrm{NO}_{3}{ }^{-}$ amended cores

\begin{tabular}{|c|c|c|c|}
\hline Station & Month & $\begin{array}{l}\mathrm{NO}_{3}^{-} \text {flux } \\
\left(\mu \mathrm{mol} \mathrm{m}{ }^{-2} \mathrm{~h}^{-1}\right)\end{array}$ & $\mathrm{NH}_{4}^{+}$flux \\
\hline \multirow[t]{4}{*}{ Büsum-I } & February'09 & $-214 \pm 73$ & $-60 \pm 26$ \\
\hline & June'09 & $-763 \pm 309$ & $537 \pm 168$ \\
\hline & November'09 & $-163 \pm 9$ & $182 \pm 4$ \\
\hline & April'10 & $-177 \pm 56$ & $33 \pm 5$ \\
\hline \multirow[t]{4}{*}{ Büsum-II } & February’09 & $-90 \pm 16$ & $87 \pm 3$ \\
\hline & June'09 & $-258 \pm 15$ & $-56 \pm 12$ \\
\hline & November'09 & $-141 \pm 3$ & $71 \pm 15$ \\
\hline & April'10 & - & - \\
\hline \multirow[t]{5}{*}{ Sylt-I } & February'09 & $-64 \pm 12$ & $107 \pm 14$ \\
\hline & May’09 & $-130 \pm 37$ & $278 \pm 93$ \\
\hline & July'09 & $-219 \pm 33$ & $490 \pm 132$ \\
\hline & November'09 & $-228 \pm 95$ & $275 \pm 49$ \\
\hline & April'10 & $-52 \pm 2$ & $22 \pm 10$ \\
\hline \multirow[t]{5}{*}{ Sylt-II } & February'09 & $-44 \pm 6$ & $-24 \pm 6$ \\
\hline & May’09 & $-102 \pm 37$ & $67 \pm 22$ \\
\hline & July'09 & $-55 \pm 20$ & $69 \pm 10$ \\
\hline & November'09 & $-41 \pm 60$ & $-5 \pm 4$ \\
\hline & April'10 & $-74 \pm 20$ & $31 \pm 20$ \\
\hline
\end{tabular}

Data are mean values of three cores $(n=3)$ with standard deviation

- data not available

according the isotope pairing technique (IPT) (Nielsen 1992) from the $\mathrm{N}_{2}$ fluxes $(\mathrm{m} 29+\mathrm{m} 30)$ of the ${ }^{15} \mathrm{NO}_{3}{ }^{-}$amended cores (Table 6) as described in "Calculation of $\mathrm{N}_{2}$ production rates from amended cores according to IPT" section. The differences between calculated $\mathrm{N}_{2}$ production rates on mass 28 $\left(\mathrm{D}_{14}\right)$ and actual $\mathrm{N}_{2}$ production rates on mass 28 are small and within the standard deviation for the respective mean $\mathrm{N}_{2}$ production rates (Tables 5, 6). Exceptions are fluxes during a sampling campaign at Sylt-II in February 2009, when fluxes calculated by IPT were higher (Table 6).

Actual $\mathrm{N}_{2}$ fluxes (m28) were highest in Büsum-I cores (130 $\mu \mathrm{mol} \mathrm{N} \mathrm{m}^{-2} \mathrm{~h}^{-1}$ ) in November 2009, and varied between 15 and $30 \mu \mathrm{mol} \mathrm{m}{ }^{-2} \mathrm{~h}^{-1}$ in Büsum-II cores. We registered no actual $\mathrm{N}_{2}$ flux (m28) during May and July 2009 in Sylt-I and Sylt-II sediments; these sediments produced $\mathrm{N}_{2}$ at rates of 32 and $13 \mu \mathrm{mol} \mathrm{N} \mathrm{m}^{-2} \mathrm{~h}^{-1}$, respectively, in February 2009. In all sediment cores, $\mathrm{N}_{2}$ fluxes in the ${ }^{15} \mathrm{NO}_{3}{ }^{-}$ amended cores were higher than actual rates during
Table $5 \quad \mathrm{~N}_{2}(\mathrm{~m} 28)$ and $\mathrm{O}_{2}$ fluxes for the unamended cores

\begin{tabular}{|c|c|c|c|}
\hline Station & Month & $\begin{array}{l}\mathrm{N}_{2}(\mathrm{~m} 28) \text { flux } \\
\left(\mu \mathrm{mol} \mathrm{m} \mathrm{m}^{-2} \mathrm{~h}^{-1}\right)\end{array}$ & $\mathrm{O}_{2}$ flux \\
\hline \multirow[t]{4}{*}{ Büsum-I } & February'09 & $120 \pm 30$ & $-823 \pm 106$ \\
\hline & June'09 & $70 \pm 10$ & $-2165 \pm 15$ \\
\hline & November'09 & $130 \pm 37$ & $-2430 \pm 217$ \\
\hline & April'10 & $58 \pm 20$ & $-1360 \pm 9$ \\
\hline \multirow[t]{4}{*}{ Büsum-ll } & February'09 & $30 \pm 8$ & $-220 \pm 30$ \\
\hline & June'09 & $30 \pm 5$ & $-876 \pm 288$ \\
\hline & November'09 & $14 \pm 8$ & $-1265 \pm 182$ \\
\hline & April'10 & $29 \pm 8$ & $-564 \pm 238$ \\
\hline \multirow[t]{5}{*}{ Sylt-I } & February'09 & $32 \pm 10$ & $-981 \pm 214$ \\
\hline & May’09 & n.d. & $-904 \pm 110$ \\
\hline & July’09 & n.d. & $-1048 \pm 135$ \\
\hline & November'09 & $15 \pm 4$ & $-2044 \pm 337$ \\
\hline & April'10 & $16 \pm 7$ & $-1392 \pm 255$ \\
\hline \multirow[t]{5}{*}{ Sylt-11 } & February’09 & $13 \pm 3$ & $-228 \pm 47$ \\
\hline & Мay’09 & n.d. & $-892 \pm 70$ \\
\hline & July’09 & n.d. & $-645 \pm 1$ \\
\hline & November'09 & $3 \pm 2$ & $-1070 \pm 137$ \\
\hline & April'10 & $7 \pm 2$ & $-474 \pm 127$ \\
\hline
\end{tabular}

Data are mean values of three cores $(n=3)$ with standard deviation

n.d. not detected

summer, as indicated by maximum rates on $\mathrm{m} 29$ and m30 in Büsum-I (m30: $176 \mu \mathrm{mol} \mathrm{N} \mathrm{N}^{-2} \mathrm{~h}^{-1}$; m29: $67 \mu \mathrm{mol} \mathrm{N} \mathrm{N}^{-2} \mathrm{~h}^{-1}$ ) in June 2009. Büsum-II yielded $69 \mu \mathrm{mol} \mathrm{N} \mathrm{N}_{2}(\mathrm{~m} 30) \mathrm{m}^{-2} \mathrm{~h}^{-1}$ and $32 \mu \mathrm{mol} \mathrm{N} \mathrm{N}_{2}$ (m29) $\mathrm{m}^{-2} \mathrm{~h}^{-1}$ during the same sampling campaign (Table 6). Maximum $\mathrm{N}_{2}$ fluxes in the ${ }^{15} \mathrm{NO}_{3}{ }^{-}$amended cores were $104 \mu \mathrm{mol} \mathrm{N} \mathrm{N}_{2}$ (m30) and $13 \mu \mathrm{mol} \mathrm{N}$ (m29) $\mathrm{m}^{-2} \mathrm{~h}^{-1}$ in Sylt-I cores in May 2009. Highest $\mathrm{N}_{2}$ fluxes of $29 \mu \mathrm{mol} \mathrm{N} \mathrm{N}_{2}(\mathrm{~m} 30) \mathrm{m}^{-2} \mathrm{~h}^{-1}$ were measured in Sylt-II cores in May 2009, whereas fluxes on m29 were not observed (Table 6).

\section{Discussion}

Our data bracket a range of environmental conditions and several salient features emerge on controls of $\mathrm{N}_{2}$ fluxes out of Wadden Sea sediments. We focus our discussion on effects of nitrate concentrations and temperature, and further evaluate the influence of sedimentary $\mathrm{C}_{\text {org }}$ content on $\mathrm{N}_{2}$ production rates. But the experimental data are also suited to differentiate 
Table $6 \mathrm{~N}_{2}(\mathrm{~m} 29+\mathrm{m} 30)$ fluxes and calculated $\mathrm{N}_{2}$ fluxes (m28) according to IPT $\left(\mathrm{D}_{14}\right)$ for the ${ }^{15} \mathrm{NO}_{3}{ }^{-}$ amended cores

\begin{tabular}{|c|c|c|c|c|}
\hline Station & Month & $\begin{array}{l}\mathrm{N}_{2}(\mathrm{~m} 29) \text { flux } \\
\left(\mu \mathrm{mol} \mathrm{m} \mathrm{m}^{-2} \mathrm{~h}^{-1}\right)\end{array}$ & $\mathrm{N}_{2}$ (m30) flux & $\mathrm{N}_{2}$ flux (IPT: $\mathrm{D}_{14}$ ) \\
\hline \multirow[t]{4}{*}{ Busum-I } & February'09 & $33 \pm 12$ & $6.2 \pm 2.4$ & $120 \pm 43$ \\
\hline & June'09 & $67 \pm 4$ & $176 \pm 7.3$ & $79 \pm 6$ \\
\hline & November'09 & $42 \pm 14$ & $9.8 \pm 9$ & $132 \pm 7$ \\
\hline & April'10 & $19 \pm 3$ & $5.8 \pm 0.8$ & $52 \pm 10$ \\
\hline \multirow[t]{4}{*}{ Busum-1l } & February'09 & $12 \pm 4$ & $2.3 \pm 1.6$ & $46 \pm 8$ \\
\hline & June'09 & $32 \pm 2$ & $69 \pm 0.3$ & $38 \pm 4$ \\
\hline & November'09 & $4 \pm 1$ & $1.8 \pm 0.7$ & $9 \pm 2$ \\
\hline & April'10 & $7 \pm 4$ & $1.4 \pm 0.5$ & $26 \pm 18$ \\
\hline \multirow[t]{5}{*}{ Sylt-I } & February'09 & $11 \pm 2$ & $6 \pm 0.8$ & $20 \pm 5$ \\
\hline & May’09 & $13 \pm 6$ & $104 \pm 33$ & $14 \pm 7$ \\
\hline & July’09 & $1 \pm 1$ & $46 \pm 12$ & $1 \pm 1$ \\
\hline & November'09 & $20 \pm 5$ & $35 \pm 13$ & $26 \pm 6$ \\
\hline & April'10 & $10 \pm 2$ & $13 \pm 6$ & $14 \pm 6$ \\
\hline \multirow[t]{5}{*}{ Sylt-11 } & February'09 & $11 \pm 2$ & $1.5 \pm 0.1$ & $47 \pm 19$ \\
\hline & May’09 & n. d. & $29 \pm 1.8$ & - \\
\hline & July’09 & n. d. & $16 \pm 0.3$ & - \\
\hline & November'09 & $2 \pm 1$ & $2.4 \pm 0.3$ & $2 \pm 1$ \\
\hline & April'10 & $4 \pm 2$ & $6.2 \pm 2.2$ & $6 \pm 4$ \\
\hline
\end{tabular}

Data are mean values of three cores $(n=3)$ with standard deviation n.d. not detected
$\mathrm{N}_{2}$ (m28) and nutrient fluxes, together with $\mathrm{N}_{2}$ fluxes from ${ }^{15} \mathrm{NO}_{3}{ }^{-}$amended cores $(\mathrm{m} 29+\mathrm{m} 30)$ allows us to estimate the amount of coupled nitrificationdenitrification in the sediment, and the amount of $\mathrm{N}_{2}$ fixation.

According to An et al. (2001), $\mathrm{N}_{2}$ production rates on mass $28\left(\mathrm{D}_{14}\right)$ estimated from IPT match actual $\mathrm{N}_{2}$ fluxes (m28) when no $\mathrm{N}_{2}$ fixation occurs. We applied equations derived by An et al. (2001) to calculate the amount of $\mathrm{N}_{2}$ fixation, and obtained negative solutions, which denote zero $\mathrm{N}_{2}$ fixation rates. $\mathrm{N}_{2}$ fixation thus plays no or only a minor role in sediments under study. In consequence, the net $\mathrm{N}_{2}$ flux (m28) measured in the unamended cores is a good approximation of the gross $\mathrm{N}_{2}$ production, because $\mathrm{N}_{2}$ consumption can be neglected. In our approach, we do not differentiate between the two different mechanisms of $\mathrm{N}_{2}$ production (anammox and denitrification). Anammox has been shown to play an important role in removing $\mathrm{rN}$ from marine ecosystems (Thamdrup and Dalsgaard 2002; Trimmer and Nicholls 2009), but within this study its contribution to the total $\mathrm{N}_{2}$ production cannot be estimated. This is because our experimental set-up did not include incubations with increasing concentrations of ${ }^{15} \mathrm{NO}_{3}{ }^{-}$ concentrations as described in Risgaard Petersen 
et al. (2003). In the following, we thus defined the gross denitrification rate as the net $\mathrm{N}_{2}$ flux (m28) or net $\mathrm{N}_{2}$ production rate $(\mathrm{m} 28)$ that includes an unknown proportion of anammox.

Because our experiments did not include incubations with different ${ }^{15} \mathrm{NO}_{3}{ }^{-}$concentrations, requirements of the classical IPT (Nielsen 1992; Steingruber et al. 2001) have not been met. But by applying the IPT equations and evaluating the $\mathrm{N}_{2}$ fluxes on $\mathrm{m} 29$ and $\mathrm{m} 30$ in the ${ }^{15} \mathrm{NO}_{3}{ }^{-}$amended cores (Table 6), we can calculate the contribution of coupled nitrificationdenitrification to the total $\mathrm{N}_{2}$ production (Nielsen 1992) as described in "Calculation of $\mathrm{N}_{2}$ production rates from amended cores according to IPT" section. The calculations suggest that between 5 and $60 \%$ of $\mathrm{N}_{2}$ flux out of Büsum and Sylt cores derives from coupled nitrification/denitrification. That significant nitrate additions are generated by nitrification corresponds to $\mathrm{N}_{2}$ fluxes observed exclusively on $\mathrm{m} 29$ in the Sylt-I cores in May 2009 (Table 6), when ambient ${ }^{14} \mathrm{NO}_{3}{ }^{-}$was not available (Table 2). Fluxes on m29 are only generated when ${ }^{15} \mathrm{NO}_{3}{ }^{-}$is mixed with ${ }^{14} \mathrm{NO}_{3}{ }^{-}$before being reduced to ${ }^{29} \mathrm{~N}_{2}$. The only possible source of ${ }^{14} \mathrm{NO}_{3}{ }^{-}$to the sediment in the Sylt area in May 2009 is nitrification within the sediment, and at rates calculated to around $15 \mu \mathrm{mol} \mathrm{m} \mathrm{m}^{-2} \mathrm{~h}^{-1}$. The ammonium fluxes (up to $500 \mu \mathrm{mol} \mathrm{m}{ }^{-2} \mathrm{~h}^{-1}$, Table 3) from Sylt-I and Büsum-I cores to oxic supernatant water suggest even higher nitrification rates, because it is estimated that $27-36 \%$ of the actual ammonium efflux may be re-oxidised to nitrate within the sediment (Sweerts et al. 1991).

The very high ammonium fluxes in the Sylt-I and Büsum-I cores coincide with the highest AA concentrations in the host sediments (Table 1), which apparently support extraordinary rates of ammonification. But dissimilatory nitrate reduction to ammonium (DNRA) may also be responsible for the high ammonium fluxes in Sylt-I and Büsum-I cores (Table 3) during summer: At that time, high nitrate fluxes (around $400 \mu \mathrm{mol} \mathrm{m}{ }^{-2} \mathrm{~h}^{-1}$ ) into the unamended Büsum-I sediment cores (Table 3) resulted in comparatively small $\mathrm{N}_{2}$ fluxes (m28) of $70 \mu \mathrm{mol} \mathrm{m} \mathrm{m}^{-2} \mathrm{~h}^{-1}$ out of the sediment (Table 5). This is good evidence that DNRA is a process that may compete with denitrification for nitrate as a substrate, but it is not a sink for reactive nitrogen as are denitrification and anammox. Up to date, DNRA has not been quantified for sediments of our study site, but it has been previously shown that carbon-rich environments (Tiedje 1987; Christensen et al. 2000) and a low redox potential of the sediments favour DNRA over denitrification (Burgin and Hamilton 2007; Gardner and McCarthy 2009). Scott et al. (2008) reported high DNRA rates in sediments related to a high SOD. Coincident with a relatively high SOD in the Sylt-I and Büsum-I sediments (Table 5) and high organic matter content (Table 1), we observed a dark sediment colour in Sylt-I and Büsum-I sediments which is a visual indication for a low redox potential that may stimulate DNRA. Apparently, a significant share of nitrate may be reduced by DNRA within these sediments and is subsequently released back into the water column as ammonium (An and Gardner 2002; Giblin et al. 2010).

Compared to the high fluxes in Sylt I and Büsum I sediments, ammonium and nitrate fluxes in Sylt-II and Büsum-II cores were much smaller (Table 3), and indicated lower overall $\mathrm{N}$-cycling rates; in these sediments, $\mathrm{O}_{2}$ penetration also was much deeper. Although an extended gradient of $\mathrm{O}_{2}$ in the Sylt-II and Büsum-II cores should favour complete nitrification of effluxing ammonium, substrate limitation and a low rate of ammonification in the organic-poor sediments (Table 1) limits nitrification: According to IPT calculations, coupled nitrification-denitrification in Sylt-II cores accounts for around $10 \%$ in November 2009 and April 2010, whereas no denitrification has been detected in summer (Table 5). It is of note that we never registered a net flux of nitrate out of the sediments under study, which means that nitrification never adds more nitrate than is being immediately reduced again. Furthermore, nitrogen consumption by $\mathrm{N}_{2}$ fixation is a negligible process (see above) and net $\mathrm{N}_{2}$ fluxes are always directed out of the sediments, meaning that most of the sediments are a sink for reactive nitrogen. Exceptions are the Sylt-I sediments with ammonium fluxes of up to $500 \mu \mathrm{mol} \mathrm{m}{ }^{-2} \mathrm{~h}^{-1}$ that exceed the nitrogen consumption rate most time of the year (Table 3). Hence, Sylt-I sediments are not a net sink, but a source of reactive nitrogen.

Nitrate and temperature effects on $\mathrm{N}_{2}$ production rates in Büsum and Sylt sediments

$\mathrm{N}_{2}$ production rates at both locations were lowest in summer (Table 5), despite of higher temperatures favouring most microbial processes (Koch et al. 


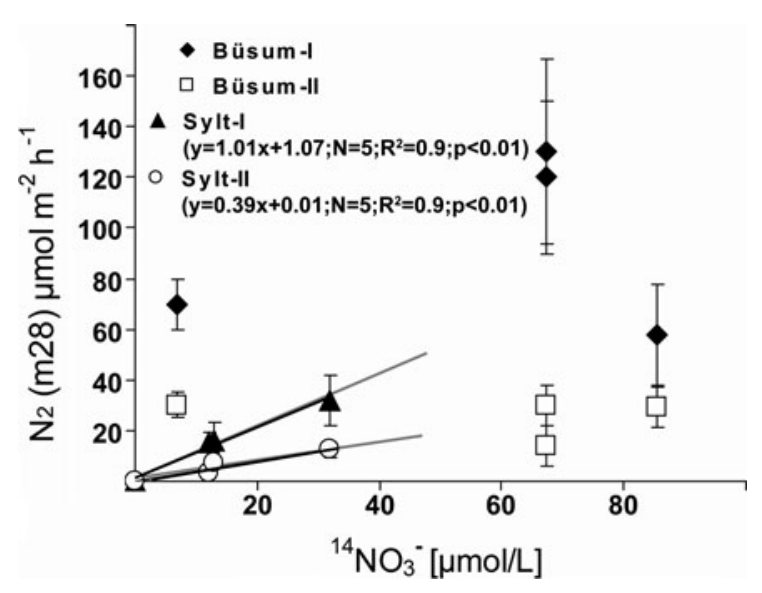

Fig. 2 Actual $\mathrm{N}_{2}$ production rates versus ambient ${ }^{14} \mathrm{NO}_{3}{ }^{-}$

1992). On the other hand, nitrate was abundant in overlying waters at these times. This observation and the fact that we did not measure actual $\mathrm{N}_{2}$ (m28) production in sediments at Sylt sites when $\mathrm{NO}_{3}{ }^{-}$was depleted in summer identify nitrate availability as one of the overriding control factors on denitrification rates. Even in the small range of ambient $\mathrm{NO}_{3}{ }^{-}$ concentrations encountered at Sylt-I and Sylt-II sampling sites (Fig. 2), actual $\mathrm{N}_{2}$ (m28) production appears to increase linearly with nitrate availability, which here is relatively low $\left(<30 \mu \mathrm{mol} \mathrm{l}^{-1}\right)$ and restricted to the cold seasons (Table 2). The linear positive relationships between actual $\mathrm{N}_{2}$ production (m28) and nitrate concentrations for the four data points for Sylt I and II sampling in Fig. 2 are significantly correlated for each sampling site ( $r^{2} \geq 0.9 ; P<0.01$ for Sylt-I and Sylt-II), but our data lack true seasonal resolution and doe not cover maximum $\mathrm{NO}_{3}{ }^{-}$concentrations of about $50 \mu \mathrm{mol} \mathrm{1^{-1 }}$ (van Beusekom et al. 2009). $\mathrm{NO}_{3}{ }^{-}$availability is a major limiting factor in denitrification (Nedwell 1982; Seitzinger and Nixon 1985; Christensen et al. 1990), when other factors, such as organic matter or temperature, are not limiting (Golterman 2004).

In the ${ }^{15} \mathrm{NO}_{3}{ }^{-}$amended incubations of Sylt cores, the $\mathrm{N}_{2}$ fluxes ( $\left.\mathrm{m} 29+\mathrm{m} 30\right)$ had maxima in summer months (Table 6), emphasizing that Sylt sediments are highly active when $\mathrm{NO}_{3}{ }^{-}$substrate is available. In response to decreasing riverine nitrogen loads, $\mathrm{NO}_{3}{ }^{-}$ concentrations have steadily decreased during summer months over the last years in the Sylt area (van Beusekom et al. 2009), and nitrate availability was found to limit denitrification in previous investigations
(Jensen et al. 1996). We conclude that denitrification (fuelled by nitrate from the overlying water column) in the nitrate-limited sector of the Wadden Sea occurs only between November and April (fall, winter and early spring) at rates between 3 and $13 \mu \mathrm{mol} \mathrm{N} \mathrm{m}^{-2}$ $\mathrm{h}^{-1}$ in coarse sands (Sylt-II), and between 15 and $32 \mu \mathrm{mol} \mathrm{N} \mathrm{m}^{-2} \mathrm{~h}^{-1}$ in fine sands (Sylt-I).

In contrast to the Sylt stations, the Büsum stations are situated near the Elbe river plume and thus permanently influenced by river-borne nitrate, which is never completely depleted (Table 2), nitrate reduction in sediments proceeds during all seasons. Still, $\mathrm{N}_{2}$ fluxes $(\mathrm{m} 29+\mathrm{m} 30)$ in the ${ }^{15} \mathrm{NO}_{3}{ }^{-}$amended cores were higher than actual $\mathrm{N}_{2}(\mathrm{~m} 28)$ fluxes in unamended cores in June 2009 (Table 5, 6), indicating that ambient nitrate concentrations around $7 \mu \mathrm{mol} \mathrm{l}^{-1}$ (Table 2) already limit actual $\mathrm{N}_{2}$ production during summer months. In contrast to the Sylt stations, there is no firm relationship between maximum $\mathrm{NO}_{3}{ }^{-}$concentrations and maximum actual $\mathrm{N}_{2}$ production (Fig. 2): Maximum nitrate concentrations occurred in April 2010, but were not associated with maximum actual $\mathrm{N}_{2}(\mathrm{~m} 28)$ production rates, which were instead measured in November 2009 (Table 5). One explanation is that temperature may control $\mathrm{N}_{2}$ production in the absence of $\mathrm{NO}_{3}{ }^{-}$limitation: Although water temperature was similar during sampling campaigns in November 2009 and April 2010, lower rates in April 2010 followed an exceptionally long and cold winter during this study, during which the sampling site was covered with ice and mean air temperatures of $-1.3^{\circ} \mathrm{C}$ chilled the coast until March (DWD 2010).

The effect of temperature on $\mathrm{N}_{2}$ production is apparent from the results of the ${ }^{15} \mathrm{NO}_{3}{ }^{-}$amended cores. Because all ${ }^{15} \mathrm{NO}_{3}{ }^{-}$amended cores received 40-50 $\mu \mathrm{mol} 1^{-1}$ of ${ }^{15} \mathrm{NO}_{3}{ }^{-}$, substrate limitation can be excluded. During sampling campaigns with temperatures above $15^{\circ} \mathrm{C}, \mathrm{N}_{2}(\mathrm{~m} 29+\mathrm{m} 30)$ fluxes in ${ }^{15} \mathrm{NO}_{3}{ }^{-}$amended cores were highest (Table 6), indicating the positive effect of temperature on denitrification rates as shown elsewhere (Seitzinger 1988; van Luijn et al. 1999). But the effect observed in our study may be influenced by additional factors, such as oxygen penetration depth, nitrate availability, primary productivity and hence substrate availability, which are all linked with temperature. Competing heterotrophic processes for organic matter, especially sulphate reduction and aerobic respiration, may also 
bias denitrification rates, so that isolated consideration of temperature only does not reflect interrelated in situ conditions. Sørensen et al. (1979), for example, observed that denitrification rates were low at times of high temperature, but attributed this to low nitrate concentrations co-occurring with higher temperatures. Because the Büsum-II and Sylt-II cores generally have lower denitrification rates than the Büsum-I and Sylt-I cores, even at high nitrate levels in the ${ }^{15} \mathrm{NO}_{3}{ }^{-}$amended cores at in situ temperatures above $15^{\circ} \mathrm{C}$, we assume that other factors besides substrate availability and temperature may be ratedetermining including organic matter content or the permeability-dependent transport of nitrate to the active site of denitrification in the sediment.

\section{Influence of sedimentary TOC content}

Maximum actual $\mathrm{N}_{2}$ fluxes (m28) for the four study sites ranged between 13 and $130 \mu \mathrm{mol} \mathrm{N} \mathrm{N}^{-2} \mathrm{~h}^{-1}$. These rates were largely determined by nitrate availability and temperature. To assess the influence of sediment type, we grouped sediments Büsum-I and Sylt-I into one sediment facies (group I) with moderate TOC content (1.6-1.9\%; Table 1), high bulk AA concentrations (7-15 $\mathrm{mg} \mathrm{g}^{-1}$; Table 1), and low oxygen penetration depths (Table 2). In contrast, the two sediment facies Büsum-II and Sylt-II have low TOC concentrations (0.1-0.6\%), low bulk AA concentrations $\left(<1 \mathrm{mg} \mathrm{g}^{-1}\right.$, Table 1$)$, and higher oxygen penetration depths (Table 2). When nitrate limitation (excluded in ${ }^{15} \mathrm{NO}_{3}{ }^{-}$amended cores) and temperature-related suppression of bacterial processes can be excluded as influences on denitrification rates in summer months (water temperatures above $15^{\circ} \mathrm{C}$; Table 2), we expected effects of sediment characteristics to emerge from the data. Indeed, $\mathrm{N}_{2}$ fluxes (m30) were highest during summer in group I sediments $\left(104-176 \mu \mathrm{mol} \mathrm{N} \mathrm{m}^{-2} \mathrm{~h}^{-1}\right.$; Table 6). In group II sediments, $\mathrm{N}_{2}$ fluxes (m30) were also highest in summer, but significantly lower than in group-I sediments (29-69 $\mu \mathrm{mol} \mathrm{N} \mathrm{N}_{2} \mathrm{~m}^{-2} \mathrm{~h}^{-1}$; Table 6). There seems to be a trend of increasing $\mathrm{N}_{2}$ production with increasing TOC content in the group I sediments, although our data set cannot be statistically evaluated because it encompasses only four different sediment types and TOC concentrations. But the tentative trend is consistent with numerous previous studies, where denitrification rates correlated positively with the TOC content (Seitzinger 1988; Sundbäck et al. 2000; Piña-Ochoa and Álvarez-Cobelas 2006; Deutsch et al. 2010).

A characteristic of sediments high in TOC and high denitrification rates is a thin oxygen penetration layer. It reflects a high sedimentary oxygen demand (SOD), high microbial biomass and a high overall microbial activity. Consistent with higher SOD in group I sediments (Table 5), the oxic zone in these cores is comparatively thin (Table 2). A thin oxic zone raises the denitrifying zone towards the sediment-water interface and implies a shorter diffusion path of nitrate, which increases the denitrification rate (Christensen et al. 1990), so that denitrification rates are inversely correlated with the oxygen penetration depth. We note that this relationship only holds for systems with high nitrate concentrations in overlying waters. In systems where nitrification in the sediments is the major source of nitrate for denitrification, a thick oxic layer may favour nitrification (Seitzinger 1988) where organic matter as a substrate for ammonification is available. In our case, deep oxygen penetration in group II sediments is accompanied by low ammonium fluxes (Table 3,4) due to organic matter limitation, which in turn may limit nitrification.

In conclusion, denitrification rates are significantly higher in group I cores that have higher TOC content and AA concentrations, but the same supply of nitrate $\left({ }^{15} \mathrm{NO}_{3}{ }^{-}\right.$amended cores) does not necessarily induce the same rate of denitrification. Consistent with assumptions made by Duff et al. (1984), we suggest that low TOC concentrations in Büsum-II and Sylt-II cores cause low denitrification rates, whereas high TOC amount and AA concentrations induce high denitrification rates in Büsum-I and Sylt-I.

An estimate of annual nitrogen removal in the northern German Wadden Sea

Our ultimate goal was to quantify the role of sedimentary nitrogen loss in the Wadden Sea, which is suspected to be a major sink for riverborne nitrate loads due to favourable boundary conditions of nitrate availability and sediment facies. Ours are the first systematic data, and although spatial and temporal resolution is admittedly rather low, we feel justified to use this data set for a first estimate of annual nitrogen removal. When calculating annual nitrogen removal, our data suggest that the 
Fig. 3 Nitrate

concentrations in the

Wadden Sea area in

February 2009 (left) and

August 2009 (right). Data

from 21 sampling stations

are from monitoring

campaigns from the

Landesamt für

Landwirtschaft, Umwelt und ländliche Räume des Landes Schleswig-Holstein done with the RV Haithabu

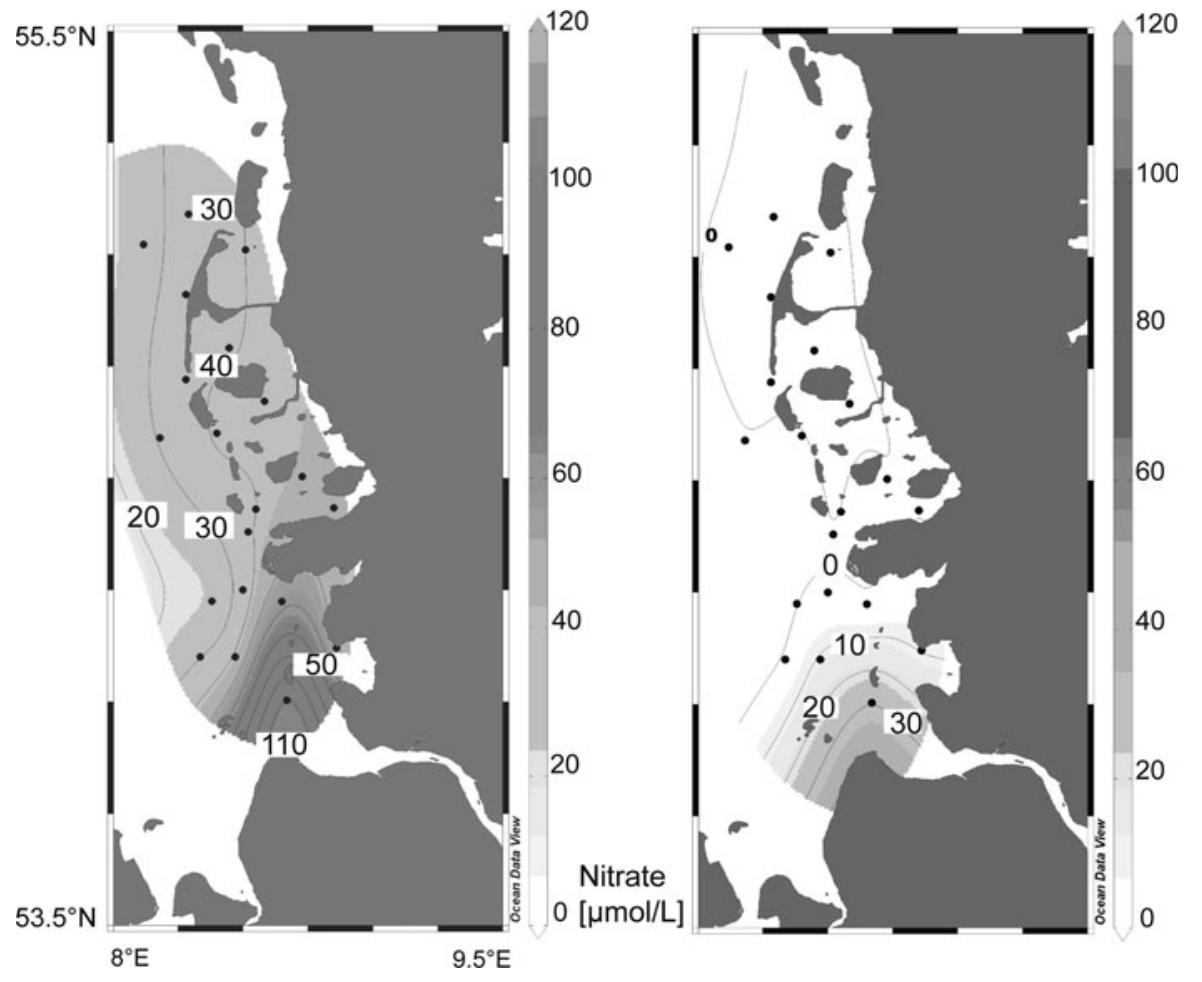

seasonality of $\mathrm{NO}_{3}{ }^{-}$concentrations and temperatures in the water body, and the sedimentary TOC content must be considered. Of these, the dominant controlling factor in the sense of net removal from the water column is the nitrate concentration in the water column. In Fig. 3 we show nitrate concentrations in the northern German Wadden Sea for February 2009 and August 2009. The nitrate distribution in February 2009 is representative for the winter months (October-April) and the nitrate distribution in August 2009 represents respective concentrations for summer months (May-September). In winter, denitrification is obviously not nitrate limited, and denitrification is potentially active in the entire north German Wadden Sea area $\left(2.100 \mathrm{~km}^{2}\right)$, whereas $3 / 4$ of the area is nitrate limited in summer (Fig. 3). From these observations we assume that actual net-removal in summer is only effective in an area of about $525 \mathrm{~km}^{2}$. Because denitrification rates also depend on permeability and the sedimentary TOC content, we have to consider the share of the individual sediment types. In the Wadden Sea, $65 \%$ of the sediments are sandy (proportion of grain size $<63 \mu \mathrm{m}$ is less than $10 \%$ ), $30 \%$ are fine sand (proportion of grain size $<63 \mu \mathrm{m}$ is between 10 and 50\%), and 5\% are muddy (proportion of grain size $<63 \mu \mathrm{m}$ is more than 50\%) (Köster 1998).

To relate the rates determined in the different sediment types studied to the gross Wadden Sea sediment composition, we assigned rates determined in group-II sediments (Büsum-II and Sylt-II) to the sandy sediment facies, and rates in the group-I sediments (Büsum-I and Sylt-I) to the fine sand facies; muddy sediments were neglected due to their limited extent. Initially, we consider the sediments detached from the actual location, so that we can estimate denitrification rates for a certain sediment group at a given season. In the present study, measured actual $\mathrm{N}_{2}$ production rates (m28) were highly dependent on location. Nitrate availability decreased with distance of the sampling site to the Elbe Estuary, which is the dominant source of nitrate in the northern Wadden Sea (van Beusekom et al. 2001). By considering total $\mathrm{N}_{2}$ production rates $(\mathrm{m} 28+\mathrm{m} 29+\mathrm{m} 30)$ from the ${ }^{15} \mathrm{NO}_{3}{ }^{-}$amended cores, we are able to estimate denitrification rates uncoupled from nitrate limitation and location. To account for seasonal temperature variation, we separated summer (sampling campaigns in May, June and July) and winter (sampling campaigns in 
February, November and April) $\mathrm{N}_{2}$ production rates. From this, we calculated mean total $\mathrm{N}_{2}$ production rate $(\mathrm{m} 28+\mathrm{m} 29+\mathrm{m} 30)$ of $49 \mu \mathrm{mol} \mathrm{N} \mathrm{m}^{-2} \mathrm{~h}^{-1}$ (sand) and $159 \mu \mathrm{mol} \mathrm{N} \mathrm{m}^{-2} \mathrm{~h}^{-1}$ (fine sand) in the summer, and 25 and $97 \mu \mathrm{mol} \mathrm{N} \mathrm{m}^{-2} \mathrm{~h}^{-1}$, respectively, in the winter seasons. We then assigned these mean seasonal $\mathrm{N}_{2}$ production rates to the percentage of sediment types as described in Köster (1998), and obtained a nitrogen removal rate of $3.8 \mathrm{mmol} \mathrm{N} \mathrm{m}^{-2}$ day $^{-1}$ in the summer and of $2.1 \mathrm{mmol} \mathrm{N} \mathrm{m}^{-2}$ day $^{-1}$ in the winter. Multiplied by the area $\left(2,100 \mathrm{~km}^{2}\right.$ in winter and $525 \mathrm{~km}^{2}$ in summer) of nitrate availability, we calculated an annual nitrogen removal rate of $16 \mathrm{kt} \mathrm{N}$ year ${ }^{-1}$ for the north German Wadden Sea area. Given a total nitrogen load of the Elbe River of 116 kt in 2006 (Radach and Pätsch 2007), about 14\% of the annual nitrogen load is removed by sedimentary $\mathrm{N}_{2}$ production. But we only calculated loss in intertidal and shallow subtidal sediments of the northern sector: Considering that the entire North Sea Wadden Sea covers an area around $8,000 \mathrm{~km}^{2}$ (including the Wadden Sea south of the Elbe River and the Dutch and Danish Wadden Sea), our estimate covers only $25 \%$ of the total Wadden Sea area. And nitrogen inputs from land may in addition be reduced by sedimentary denitrification, and anammox as well, in estuaries, and over an area of $750.000 \mathrm{~km}^{2}$ in the offshore North Sea that have not been evaluated in this study.

Our estimate of an annual nitrogen removal rate is poorly constrained, mainly because of the low number of sites examined. Furthermore, there is a source of potentially significant error in our approach and the data set, because the applied experimental set-up did not imitate advective pore water transport and the overall influence of tidal cycling. The Wadden Sea is characterized by semi-diurnal tides and highly dynamic transport processes with different exposure times during low tide comparing subtidal and intertidal sediments. Advective pore water transport dominates during high tide and diffusive transport takes over during low tide exposure of permeable sediments (Huettel et al. 2003). Nutrient supply from the overlying water column and nutrient pore water concentrations show high variability over the tidal cycle, so that in situ denitrification rates are expected to be more variable than under steady state conditions assumed in the experimental design used here.
The rates measured in the sandy sediment facies in particular are likely to underestimate in situ rates at the sea floor. During high tide, nitrate is permanently flushed into permeable sediments (de Beer et al. 2005; Cook et al. 2006; Rao et al. 2007; 2008), which was not sufficiently imitated in the set-up of our flowthrough incubations. According to Gihring et al. (2010), denitrification rates are up to ten times higher in percolated than in stirred set-ups. Recently, Gao et al. (2010) measured high potential denitrification rates $\left(>80 \mu \mathrm{mol} \mathrm{N} \mathrm{m}^{-2} \mathrm{~h}^{-1}\right)$ in a percolation experiment with sediment cores from permeable sand in the southern German Wadden Sea area.

Nevertheless, $\mathrm{N}_{2}$ production rates obtained in this study and the estimated annual nitrogen loss are relatively high compared to other studies from the 1990's, which were mostly conducted in offshore sediments (van Raaphorst et al. 1990, 1992; Law and Owens 1992; Lohse et al. 1993, 1996). Comparable studies by Kieskamp et al. (1991) in intertidal Wadden Sea sediments estimated an average denitrification potential of $0.3 \mathrm{mmol} \mathrm{N} \mathrm{m}{ }^{-2}$ day $^{-1}$. We attribute these relatively low older rate estimates to the acetylene-block-technique used at the time. Higher denitrification rates in Wadden Sea sediments have since been obtained with the isotope pairing technique (Jensen et al. 1996), who measured maximum rates of $1.2 \mathrm{mmol} \mathrm{N} \mathrm{m}^{-2} \mathrm{day}^{-1}$ in spring. In a mass-balance estimate by van Beusekom et al. (1999), the Wadden Sea was expected to remove nitrate at a (then considered excessive) rate of approximately $1.6 \mathrm{mmol} \mathrm{N} \mathrm{m}{ }^{-2}$ day $^{-1}$. Our findings suggest even higher nitrogen removal rates of 2.1-3.8 mmol N m${ }^{-2}$ day $^{-1}$ estimated from sediment core incubations. As explained above, this estimate may still be too low, because actual rates in permeable sands are likely to be higher than in our experiments (Gao et al. 2010). Therefore, we feel that our estimate for the Wadden Sea probably underestimates the potential of sediments in the coastal ocean for nitrogen removal and mitigation of river-induced eutrophication.

\section{Conclusions}

In this study we presented a first data set about seasonally varying $\mathrm{N}_{2}$ production rates in typical sediments of the German Wadden Sea. The results of 
our study suggest that major factors controlling nitrogen loss in coastal sediments of the German Bight are the nitrate concentrations in the water body, the temperature influencing biological activity, and the organic matter content of the sediment type. Sedimentary $\mathrm{N}_{2}$ production rates increase with increasing nitrate delivery, suggesting that gross $\mathrm{N}$ loss increases in the vicinity of the nitrate advecting Elbe River plume. Whereas nitrogen removal in sediments at the island of Sylt are nitrate limited during summer months, $\mathrm{N}_{2}$ production proceeds during all season in the Meldorf Bight situated in the outer Elbe Estuary. Experiments with ${ }^{15} \mathrm{NO}_{3}{ }^{-}$ revealed that Wadden Sea sediments have a high potential to remove nitrate if it is abundant and available, thus providing an internal mechanism counteracting eutrophication by high river loads. In an extrapolation of seasonal mean $\mathrm{N}_{2}$ production rates classified into different sediment types, we arrive at weighted nitrogen removal rates between 2.1 and $3.8 \mathrm{mmol} \mathrm{N} \mathrm{m}^{-2}$ day $^{-1}$, suggesting intense nitrogen turnover in the entire Wadden Sea. Although further experiments in different sediment types and under varying conditions are required to exactly quantify nitrogen removal rates for the Greater North Sea area, it is clear that the near shore sedimentary nitrate sink accounts for a large share of the overall natural attenuation of man-induced eutrophication.

Acknowledgments We thank the Helmholtz-Zentrum Geesthacht, Institute for Coastal Research and the DFG (Em 37/29) for financial support. In particular, we thank W.S. Gardner and M.J. McCarthy (Marine Science Institute, University of Texas at Austin) for their helpful introduction to sediment incubation. We acknowledge N. Lahajnar and F. Langenberg (IfBM, University of Hamburg) for supervising work on the data set of sediment characteristics. We thank the FTZ Westküste, Büsum and the AWI, List for providing laboratory space and our technician M. Ankele for assistance during field trips. A. Wieland is acknowledged for an introduction into oxygen profiling, corrections and helpful comments on an earlier draft.

\section{References}

An S, Gardner WS (2002) Dissimilatory nitrate reduction to ammonium (DNRA) as a nitrogen link versus denitrification as a sink in a shallow estuary (Laguna Madre/ Baffin Bay, TX). Mar Ecol-Prog Ser 237:41-50

An S, Gardner WS, Kana T (2001) Simultaneous measurement of denitrification and nitrogen fixation using isotope pairing with membrane inlet mass spectrometry analysis. Appl Environ Microbiol 67:1171-1178

Armstrong FAJ, Sterns CR, Strickland JDH (1967) The measurement of upwelling and subsequent biological processes by means of the Technicon AutoAnalyzer and associated equipment. Deep-Sea Res 14:381-389

Brewer PG, Riley JP (1966) The automatic determination of silicate-silicon in natural waters with special reference to sea water. Anal Chim Acta 35:514-519

Brion N, Baeyens W, De Galan S, Elskens M, Laane RW (2004) The North Sea: source or sink for nitrogen and phosphorus to the Atlantic Ocean? Biogeochemistry 68:277-296

Burgin AJ, Hamilton SK (2007) Have we overemphasized denitrification in aquatic ecosystems: a review of nitrate removal pathways. Front Ecol Environ 5:89-96

Christensen PB, Nielsen LP, Sörensen J, Revsbech NP (1990) Denitrification in nitrate rich streams: diurnal and seasonal variation related to benthic oxygen metabolism. Limnol Oceanogr 35:640-651

Christensen PB, Rysgaard S, Sloth NP, Dalsgaard T, Schwaerter S (2000) Sediment mineralization, nutrient fluxes, denitrification and dissimilatory nitrate reduction to ammonium in an estuarine fjord with sea cage trout farms. Aq Micro Ecol 21:73-84

Cook PLM, Wenzhöfer F, Rysgaard S, Galaktionov OS, Meysman FJR, Eyre BD, Cornwell J, Huettel M, Glud RN (2006) Quantification of denitrification in permeable sediments: insights from a two-dimensional simulation analysis and experimental data. Limnol Oceanogr Method 4:294-307

Cornwell JC, Kemp WM, Kana TM (1999) Denitrification in coastal ecosystems. Aquat Ecol 33:41-54

de Beer D, Wenzhöfer F, Ferdelman TG, Boehme SE, Huettel M, van Beusekom JEE, Böttcher ME, Musat N, Dubilier N (2005) Transport and mineralization rates in North Sea sandy intertidal sediments, Sylt-Røm $\varnothing$ Basin, Waddensea. Limnol Oceanogr 50:113-127

Deutsch B, Forster S, Wilhelm M, Dippner JW, Voss M (2010) Denitrification in sediments as a major nitrogen sink in the Baltic Sea: an extrapolation using sediment characteristics. Biogeoscie Disc 7:2487-2521

Duff JH, Triska FJ, Oremland RS (1984) Denitrification associated with stream Periphyton: chamber estimates from undisrupted communities. J Environ Qual 13:514-518

DWD (2010) Deutscher Wetterdienst, Presse- und Öffentlichkeitsarbeit. Deutschlandwetter im Winter 2009/ 2010. http://www.dwd.de/bvbw/generator/DWDWWW/ Content/Presse/Pressemitteilungen/2010/20100226__Deut schlandwetter_Winter_2009_2010,templateId=raw, pro perty=publicationFile.pdf/20100226_Deutschlandwetter_ Winter_2009_2010.pdf. Accessed 7 June 2010

Eyre BD, Rysgaard S, Dalsgard T, Christensen PB (2002) Comparison of Isotope Pairing and $\mathrm{N}_{2}$ :Ar methods for measuring sediment denitrification: assumptions, modifications, and implications. Estuaries 25:1077-1087

Gao H, Schreiber F, Collins G, Jensen MM, Kostka JE, Lavik G, de Beer D, Zhou H, Kuypers MMM (2010) Aerobic denitrification in permeable Wadden Sea sediments. ISME J 4(3):417-426 
Gardner WS, McCarthy MJ (2009) Nitrogen dynamics at the sediment-interface in shallow, sub-tropical Florida Bay: why denitrification efficiency may decrease with increased eutrophication. Biogeochemistry 95:185-198

Gardner WS, Seitzinger SP, Malczyk JM (1991) The effects of sea salts on the forms of nitrogen released from estuarine and freshwater sediments: does ion pairing affect ammonium flux? Estuaries 14:157-166

Giblin AE, Weston NB, Banta GT, Tucker J, Hopkinson CS (2010) The effects of salinity on nitrogen losses from an oligohaline estuarine sediment. Estuar Coast 33:1054-1068

Gihring TM, Canion A, Riggs A, Huettel M, Kostka JE (2010) Denitrification in shallow, sublittoral Gulf of Mexico permeable sediments. Limnol Oceanogr 55:43-54

Golterman HL (2004) The chemistry of phosphate and nitrogen compounds in sediments. Kluwer Academic Publishers, Dordrecht

Grasshoff K, Ehrhardt M, Kremling K (1983) Methods of seawater analysis. Verlag Chemie, Weinheim

Huettel M, Roy H, Precht E, Ehrenhauss S (2003) Hydrodynamical impact on biogeochemical processes in aquatic sediments. Hydrobiol 494:231-236

Hydes DJ, Kelly-Gerreyn BA, Le Gall AC, Proctor R (1999) The balance of supply of nutrients and demands of biological production and denitrification in a temperate latitude shelf sea-a treatment of the southern North Sea as an extended estuary. Mar Chem 68:117-131

Jensen KM, Jensen MH, Kristensen E (1996) Nitrification and denitrification in Wadden Sea sediments (Königshafen, Island of Sylt, Germany) as measured by nitrogen isotope pairing and isotope dilution. Aquat Microb Ecol 11: 181-191

Kana TM, Darkangelo C, Hunt MD, Oldham JB, Bennett GE, Cornwell JC (1994) Membrane inlet mass spectrometer for rapid high-precision determination of $\mathrm{N}_{2}, \mathrm{O}_{2}$, and $\mathrm{Ar}$ in environmental water samples. Anal Chem 66:4166-4170

Kieskamp WM, Lohse L, Epping E, Helder W (1991) Seasonal variation of denitrification rates and nitrous oxide fluxes in intertidal sediments of the western Wadden Sea. Mar Ecol-Prog Ser 72:145-151

Koch MS, Maltby E, Oliver GA, Bakker SA (1992) Factors controlling denitrification rates of tidal mudflats and fringing salt marshes in south-west England. Estuar Coast Shelf S 34:471-485

Köster R (1998) Wattsedimente. In: Umweltatlas Wattenmeer, Bd I: Nordfriesisches und Dithmarscher Wattenmeer. Ulmer-Verlag, Stuttgart, pp 40-41

Lavrentyev PJ, Gardner WS, Yang L (2000) Effects of the zebra mussel on nitrogen dynamics and the microbial community at the sediment-water interface. Aquat Microb Ecol 21:187-194

Law CS, Owens NJP (1992) Denitrification and nitrous oxide in the North Sea. Neth J Sea Res 25:65-74

Lohse L, Malschaert JFP, Slomp CP, Helder W, van Raaphorst W (1993) Nitrogen cycling in North Sea sediments: interaction of denitrification and nitrification in offshore and coastal areas. Mar Ecol-Prog Ser 101:283-296

Lohse L, Kloosterhuis R, van Raaphorst W, Helder W (1996) Denitrification rates in continental shelf sediments of the North Sea: acetylene block technique versus isotope pairing. Mar Ecol-Prog Ser 132:169-179
McCarthy MJ, Gardner WS (2003) An application of membrane inlet mass spectrometry to measure denitrification in a recirculating mariculture system. Aquaculture 218:341-355

Middelburg JJ, Soetaert K (2004) The role of sediments in shelf ecosystem dynamics. In: Robinson AR, McCarthy J, Rothschild, BJ (eds) The Sea,vol 13, pp 353-373

Middelburg JJ, Soetaert K, Herman PMJ, Heip C (1996) Denitrification in marine sediments: a model study. Global Biogeochem Cy 10:661-673

Murphy J, Riley JP (1962) A modified single solution method for the determination of phosphate in natural waters. Anal Chim Acta 27:31-36

Nedwell DB (1982) Exchange of nitrate, and the products of bacterial nitrate reduction, between seawater and sediment from a U.K. saltmarsh. Estuar Coast Shelf S 14:557-566

Nielsen LP (1992) Denitrification in sediment determined from nitrogen isotope pairing. FEMS Microbiol Lett 86:357-362

Nixon SW, Atkinson LP, Berounsky VM, Billén G, Boicourt WC, Boynton WR, Church TM, Ditoro DM, Elmgren R, Garber JH, Giblin AE, Jahnke RA, Owens NJP, Pilson MEQ, Seitzinger SP (1996) The fate of nitrogen and phosphorus at the land-sea margin of the North Atlantic Ocean. Biogeochemistry 35:141-180

Owens NJP, Woodward EMS, Aiken J, Bellan IE, Rees AP (1990) Primary production and nitrogen assimilation in the North Sea during July 1987. Neth J Sea Res 25:143-154

Pätsch J, Serna A, Dähnke K, Schlarbaum T, Johannsen A, Emeis K (2010) Nitrogen cycling in the German Bight (SE North Sea): clues from modelling stable nitrogen isotopes. Cont Shelf Res 30:203-213

Pettijohn FJ, Potter PE (1972) Sand and sandstone. Springer, New York

Piña-Ochoa E, Álvarez-Cobelas M (2006) Denitrification in aquatic environments: a cross-system analysis. Biogeochemistry $81: 111-130$

Radach G, Pätsch L (2007) Variability of continental riverine freshwater and nutrient inputs into the North Sea for the years 1977-2000 and its consequences for the assessment of eutrophication. Est and Coasts 30:66-81

Rao AMF, McCarthy MJ, Gardner WS, Jahnke A (2007) Respiration and denitrification in permeable continental shelf deposits on the South Atlantic bight: rates of carbon and nitrogen cycling from sediment column experiments. Cont Shelf Res 27:1801-1819

Rao AMF, McCarthy MJ, Gardner WS, Jahnke A (2008) Respiration and denitrification in permeable continental shelf deposits on the South Atlantic bight: $\mathrm{N}_{2}$ :Ar and isotope pairing measurements in sediment column experiments. Cont Shelf Res 28:602-613

Risgaard Petersen NLP, Nielsen S, Rysgaard DT, Meyer RL (2003) Application of the isotope pairing technique in sediments where anammox and denitrification coexist. Limnol Oceanogr: Methods 1:63-73

Scott JT, McCarthy MJ, Gardner WS, Doyle RD (2008) Denitrification, dissimilatory nitrate reduction to ammonium, and nitrogen fixation along a nitrate concentration gradient in a created freshwater wetland. Biogeochemistry 87:11-99

Seitzinger SP (1988) Denitrification in freshwater and coastal marine ecosystems: Ecological and geochemical significance. Limnol Oceanogr 33:702-724 
Seitzinger S, Nixon SW (1985) Eutrophication and the rate of denitrification and $\mathrm{N}_{2} \mathrm{O}$ production in coastal marine sediments. Limnol Oceanogr 30:1332-1339

Sørensen J (1978) Denitrification rates in a marine sediment as measured by the acetylene inhibition technique. Appl Environ Microbiol 36:139-143

Sørensen J, Jørgensen BB, Revsbech NP (1979) A comparison of oxygen, nitrate and sulfate respiration in coastal marine sediments. Mar Ecol 5:105-115

Steingruber SM, Friedrich J, Gächter R, Wehrli B (2001) Measurement of denitrification with the ${ }^{15} \mathrm{~N}$ isotope pairing technique. Appl Env Microbiol 9:3771-3778

Sundbäck K, Miles A, Göransson E (2000) Nitrogen fluxes, denitrification and the role of micro-phytobenthos in microtidal shallow-water sediments: an annual study. Mar Ecol-Prog Ser 200:59-76

Sweerts JP, Bär-Gilissen MJ, Cornelese AA, Cappenberg TE (1991) Oxygen-consuming processes at the profundal and littoral sediment-water interface of a small meso-eutrophic lake (Lake Vechten, The Netherlands). Limnol Oceanogr 36:1124-1133

Thamdrup B, Dalsgaard T (2002) Production of $\mathrm{N}_{2}$ through anaerobic ammonium oxidation coupled to nitrate reduction in marine sediments. Appl Environ Microb 68:13121318

Tiedje JM (1987) Ecology of denitrification and dissimilatory nitrate reduction to ammonium. In: Zehnder AJB (ed) Biology of anaerobic microorganims. Wiley, New York, pp 179-244

Trimmer M, Nicholls JC (2009) Production of nitrogen gas via anammox and denitrification in intact sediment cores along a continental shelf to slope transect in the North Atlantic. Limnol Oceanogr 54:577-589

van Beusekom JEE, de Jonge VN (2002) Long-term changes in Wadden Sea nutrient cycles: importance of organic matter import from the North Sea. Hydrobiologia 475(476): 185-194

van Beusekom JEE, van de Jonge VN (1998) Retention of phosphorus and nitrogen in the Ems Estuary. Estuaries 21:527-539

van Beusekom JEE, Brockmann UH, Hesse KJ, Hickel W, Poremba K, Tillmann U (1999) The importance of sediments in the transformation and turnover of nutrients and organic matter in the Wadden Sea and German Bight. Ger J Hydrography 51:245-266

van Beusekom JEE, Fock H, de Jong F, Diel-Christiansen S, Christiansen B (2001) Wadden Sea specific eutrophication criteria. Wadden Sea Ecosystem 14:1-115

van Beusekom JEE, Loebl M, Martens P (2009) Distant riverine nutrient supply and local temperature drive the longterm phytoplankton development in a temperate coastal basin. J Sea Res 61:26-33

van Luijn F, Boers CM, Lijklema L, Sweerts JPRA (1999) Nitrogen fluxes and processes in sandy and muddy sediments from a shallow eutrophic lake. Water Res 33:33-42

van Raaphorst W, Kloosterhuis HT, Cramer A, Bakker KJM (1990) Nutrient early diagenesis in the sediments of the Dogger Bank area, North Sea: pore water results. Neth J Sea Res 26:25-52

van Raaphorst W, Kloosterhuis HT, Berghuis EM, Gieles AJM, Malschaert JFP, van Noort GJ (1992) Nitrogen cycling in two types of sediments of the Southern North Sea (Frisian Front, Broadfourteens): field data and mesocosm results. Neth J Sea Res 28:293-316

Weiss RF (1970) The solubility of nitrogen, oxygen and argon in water and seawater. Deep Sea Res Oceanographic Abstracts 17:721-735

Wentworth CK (1922) A scale of grade and class terms for clastic sediments. J Geo 30(5):377-392 